\title{
LEAD SEALINGS DISCOVERED IN THE CANABAE AND IN THE ROMAN LEGIONARY FORTRESS IN POTAISSA
}

\begin{abstract}
We present in the following four interesting unpublished artifacts found during archaeological excavations (2012-2018) in the legionary fortress and the canabae of legio V Macedonica in Potaissa (today Turda, Cluj County, Romania). All are military lead sealings. Two of them have the print in negative of LVM, placed in a cartridge. We extended the discussion by analyzing some analogies from the Roman Empire. We end our short contribution trying to explain the presence of such artifacts in Potaissa.
\end{abstract}

Keywords: lead sealings, Potaissa, fortress of legio V Macedonica, canabae of legio VMacedonica.

\section{INTRODUCTION}

$\mathbf{T}$ he legionary fortress of Legio V Macedonica is located on a plateau called Dealul Cetății (Fortress' Hill), in the western part of today's Turda (Cluj County) (Fig. 1). ${ }^{1}$ It is a medium sized legionary fortress, with a total surface of 23.34 ha. The systematic archaeological research on this site began in the year 1971 and it is being carried out to our present days, without interruptions. So far, several important books on Potaissa were published, on topics regarding the legion, ${ }^{2}$ the city, ${ }^{3}$ the architecture of the fortress, ${ }^{4}$ the coins, ${ }^{5}$ the inscriptions, ${ }^{6}$ the sculptural and funerary monuments, ${ }^{7}$ and the barracks from praetentura sinistra. ${ }^{8}$ The volume dealing with the thermal complex of the fortress is in print. $^{9}$

Our paper presents four lead sealings discovered in the legionary fortress and the canabae of Potaissa. One was discovered in the principia, another one in the thermal complex, and another one in the praetentura sinistra, in the area of the barracks. The fourth one was discovered due to some archaeological excavations executed in the former area of the canabae. All are military lead sealings, a category of finds never documented before in Potaissa.

\footnotetext{
BĂRBULESCU 2015, 16, Fig.1.

2 BĂRBULESCU 1987.

3 BĂRBULESCU 1994.

${ }^{4}$ BĂRBULESCU 2004.

PÎSLARU 2009.

BĂRBULESCU 2012.

BĂRBULESCU 2015.

${ }^{8}$ NEMETI et aliii 2017.

9 BĂRBULESCU et alii 2019.
}

\section{Florin FODOREAN}

University Babeș-Bolyai of Cluj-Napoca fodorean f@yahoo.com

\section{loana MĂRINCEAN}

University Babeș-Bolyai of Cluj-Napoca ioanna0121@gmail.com

DOI: $10.14795 /$ j.v7i1.470

ISSN 2360 - 266X

ISSN-L 2360 - 266X 


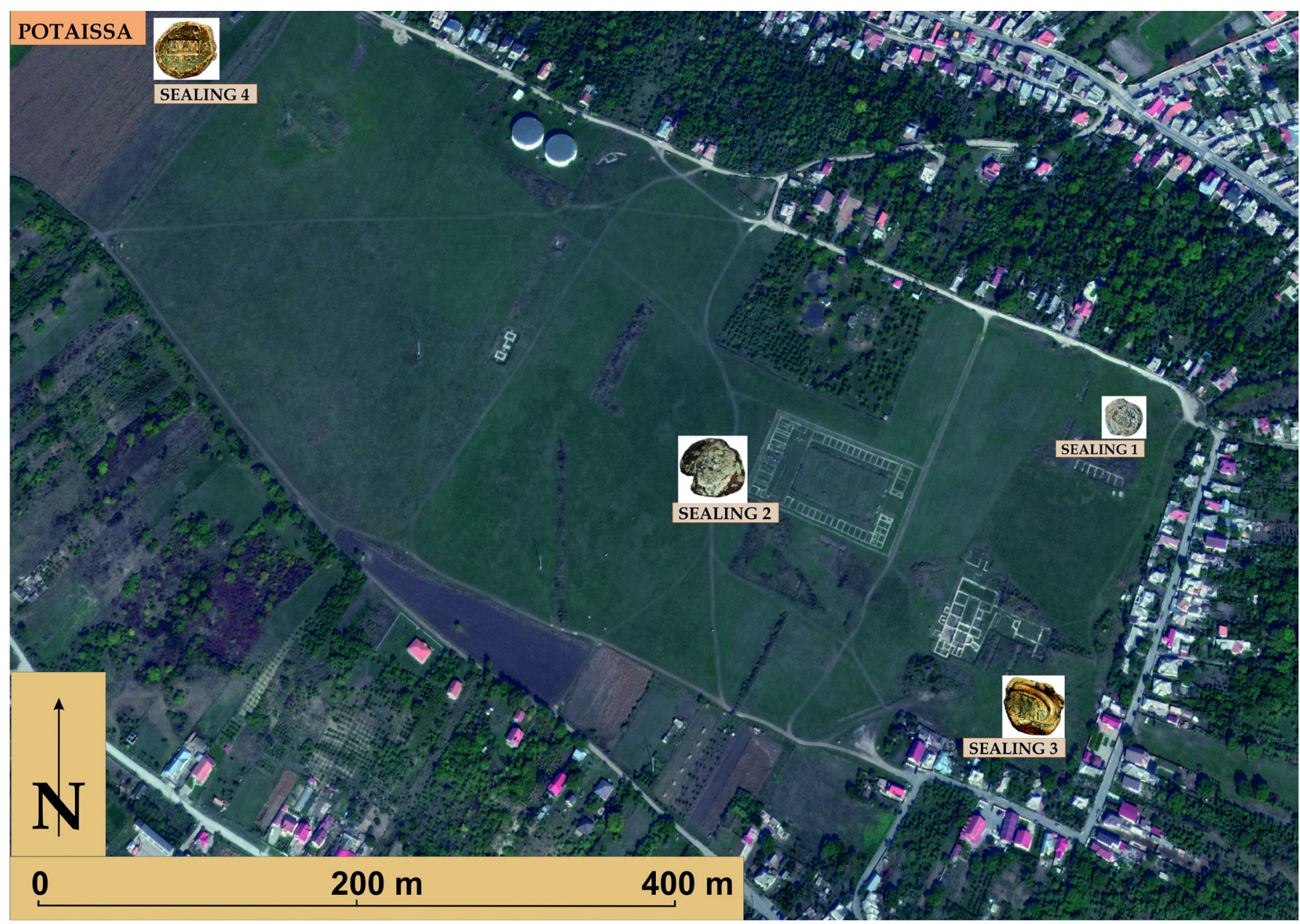

Fig. 1. The legionary fortress from Potaissa and the area of the canabae with the location of the four lead sealings. Source of the image: Google Earth.

\section{Catalogue}

1. Sigillium, made of lead, preserved almost entirely with the print in negative of LVM, placed in a cartridge (Fig. 2a, Fig. 2b). Place of discovery: section 01/2012, depth $0.60 \mathrm{~m}$, close to the via principalis, in a space situated south-east of these barracks. The inscription is L(egionis) $V$ (quintae) M(acedonicae). Diameter: $1.9 \mathrm{~cm}$. Dimensions of the cartridge: 1 x $0.4 \mathrm{~cm}$. Thickness: $0.5 \mathrm{~cm}$. Sigillium of type 5 , according to the classification made by Michael Charles William Still. ${ }^{10}$ National Museum of Transylvanian History, inv. no. v64321.
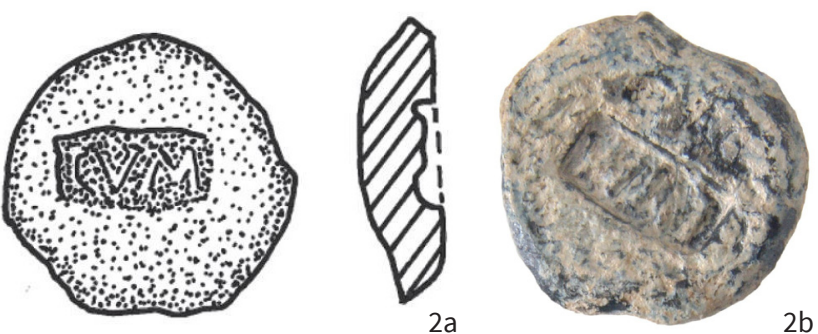

Fig. 2a, 2b. The sealing from the centuriae of the praetentura sinistra.

2. Sigillium, made of lead, preserved almost entirely (Fig. 3a, Fig. 3b). Place of discovery: principia. The outer part of the seal has a shape of a protuberance. Without any

\footnotetext{
${ }_{10}$ WILLIAM STILL 1995, I, 42-45.
}

inscription or other writing elements. Diameter: $1.5 \mathrm{~cm}$. The lead sealing has also an orifice of $0.2 \mathrm{~cm}$. Thickness: $1.2 \mathrm{~cm}$. Sigillium of type $5 .{ }^{11}$ Museum of History Turda, without inv. no.
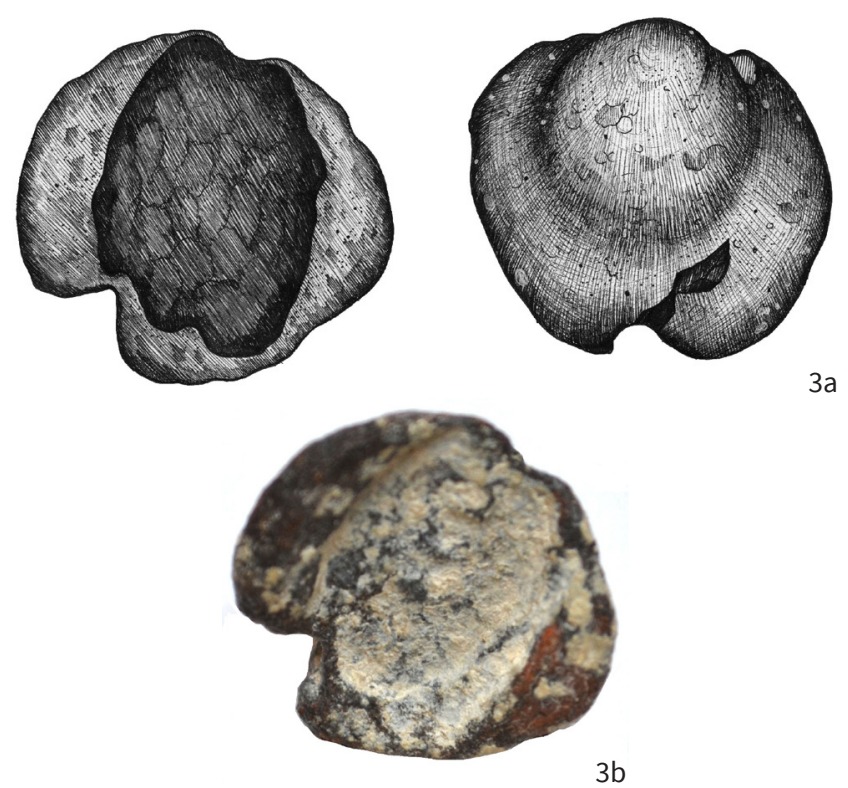

$3 a$

Fig. 3a, 3b. The sealing discovered in the principia.

\footnotetext{
${ }^{11}$ WILLIAM STILL 1995, I, 42-45.
} 
3. Sigillium, made of lead, with one size broken (Fig. 4a, Fig. 4b). Place of discovery: the thermal complex, section 8/2007, depth $0.40 \mathrm{~m}$. Diameter: $1.9 \mathrm{~cm}$. Thickness: $0.9 \mathrm{~cm}$. Sigillium of type $5 .{ }^{12}$ Museum of History Turda, inv. no. 16848 .
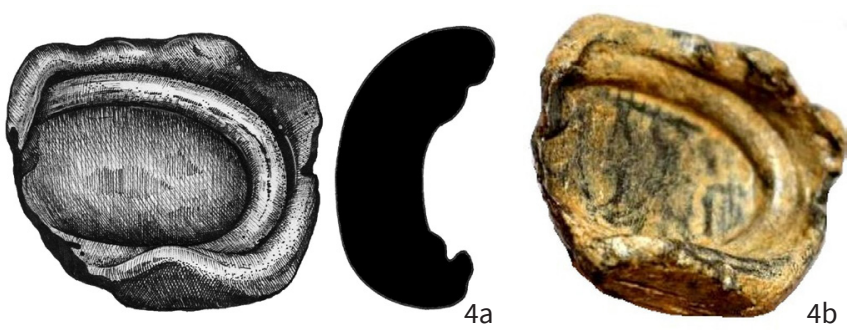

Fig. 4a, 4b. The sealing discovered inside the thermal complex.

4. Sigillium, made of lead, preserved entirely, with the print in negative of LVM, placed in a cartridge (Fig. 5a, Fig. 5b). Place of discovery: the canabae of the legionary fortress, I. I. Russu Street, section 01/2016, depth $0.50 \mathrm{~m}$. The inscription is L(egionis) V(quintae) M(acedonicae). A small orifice is positioned close to the cartridge. The outer side is flat. Diameter: $1.7 \mathrm{~cm}$. Thickness: $0.4 \mathrm{~cm}$. Sigillium of type $6 .{ }^{13}$ Museum of History Turda, inv. no. 23369.
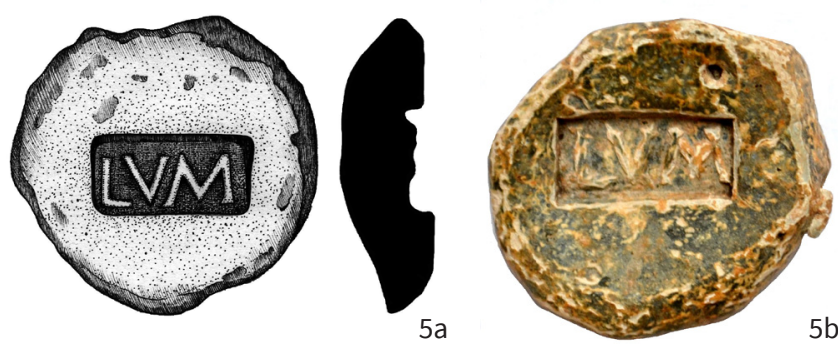

Fig. $\mathbf{5 a}$, 5b. The sealing discovered in the canabae.

\section{ARCHAEOLOGICAL AND HISTORICAL COMMENTS REGARDING THE SEALINGS}

W. Still grouped all the lead sealings known in the Roman Empire. ${ }^{14}$ He managed to create an updated catalogue of almost 2000 sealings. None is recorded in Dacia. In fact, the author emphasized that military sealings are absent from other provinces. He offered the example of Britain, when so many artifacts of this type were found, in comparison with other areas, such as Germania Superior or Inferior, where no sealings were found. The absence of the sealings from certain provinces was explained by William Still in 1995 in two ways: 1. In some areas it was not required such a strict control or security of the merchandise; 2. More likely, in some areas, people used different methods or materials for sealing. ${ }^{15}$ Also the hazard of archaeology should be taken into account. The main argument for this statement is the case of Potaissa. Until recent years, no lead sealings were found here.

The need for a detailed corpus on Roman lead sealings was highlighted in the last 40 years by several authors, like

\footnotetext{
12 WILLIAM STILL 1995, I, 42-45.

13 WILLIAM STILL 1995, I, 45-46.

14 WILLIAM STILL 1995.

15 WILLIAM STILL 1995, I, 104-109.
}

R. Turcan, ${ }^{16}$ P. Vons,${ }^{17}$ or G. Dembski. ${ }^{18}$ At the beginning of the $\mathrm{XX}^{\text {th }}$ century, in 1900, M. Rostovtzeff and M. Prou have published a book on the same topic. ${ }^{19}$

Since the publication of William Still's Ph.D. thesis in 1995 , obviously other lead sealings were discovered in different sites, especially because of the generalization of the use of metal detectors by the archaeologists.

\section{THE LEAD SEALINGS FROM POTAISSA. CONCLUSIONS}

W. Still created a typology of the Roman lead sealings, mainly based on their shape. He included in this typology ten types: 1. Two-sided with different sized obverse and reverse resulting in flange around flan; 2 . Two-sided with various shapes of flan; 3 . Two-sided with squared-off appearance due to having been cut from a lead bar; 4 . Two-sided consisting of two plates, joined by a strip, clipped together; 5 . One-sided with swelling on blank reverse; 6 . One-sided with flat reverse; 7. One-sided rectangular mould-formed bars; 8 . One-sided with central nipple on reverse; 9 . One-sided with pedestalfoot projection on reverse; 10 . One-sided consisting of two plates. ${ }^{20} \mathrm{He}$ also divided the sealings into seven categories: 1 . Imperial sealings; 2 . Official sealings; 3 . Taxation sealings; 4. Provincial sealings; 5. Civic sealings; 6. Military sealings; 7. Miscellaneous sealings. ${ }^{21}$

The analogies for the sealings from Potaissa are interesting and they deserve a short commentary. From a total of almost 2000 sealings catalogued by W. Still, 56 were found in legionary fortresses, as follows: 36 in Britain, one in Dalmatia, 13 in Gallia Lugdunensis, one in Germania Superior, four in Moesia Inferior and one in Syria. In Britain, 14 sealings were found in Brough under Stainmore, one in Caerleon, six in Carlisle, one in Cirencester, four in Corbridge, two in Kirkby Thore, two in Leicester, one in Rudchester, two in South Shields and three in unknown places. Only one sigillium was discovered in Dalmatia, in Gardun. All the 13 artifacts from Gallia Lugdunensis were found in Lyon. Only one sigillium was found in Germania Superior, at Ehl. Three sealings were discovered in Moesia Inferior, all of them from Silista. Finally, one seal was discovered in Syria, in Beirut. ${ }^{22}$

The major part of these lead sealings which mention legions presents information on both sides. Still, some of them have data only on one side: two in Britannia, one in Dalmatia, seven in Gallia Lugdunensis, all four sealings from Moesia Inferior and the sealing from Syria. For Britannia, W. Still mentions that the major part of sealings have mentions on both sides, which denotes, in his opinion, a more rigid, bureaucratic system here in comparison with other provinces. ${ }^{23}$ Numerous sealings mention the name of the legion, in short, and the expression ex(ped)i(vit). The major part of the sealings from Britannia were found

\footnotetext{
6 TURCAN 1987, 10.

7 VONS 1980, 4-53.

18 DEMBSKI 1975, 49-64.

ROSTOVTZEFF/PROU 1900, especially the first chapter: Plombes militaires, 21-28.

${ }^{20}$ WILLIAM STILL 1995, I, 35-53.

21 WILLIAM STILL 1995, I, 54-134.

22 WILLIAM STILL 1995, I, 102-109.

${ }^{23}$ WILLIAM STILL 1995, I, 102-103.
} 
in Brough under Stainmore. ${ }^{24} 131$ seals were discovered here in a garbage dump, together with other artifacts dated in the third century A.D., when unpacked merchandise arrived here, then it was sealed and send further away to the central administration. A different situation was in Carlisle (the Roman city and fort of Luguvalium), where all the six sealings were discovered inside the fort, in different points, which denotes the fact that those who unpacked the packages, obviously the soldiers, removed the sealings and threw them away not far away. ${ }^{25}$

In Potaissa such scenarios are difficult to prove. Still, it is possible that some of the sealings discovered here may come from packages with merchandise intended for the legion, such as bags or anything else, which needed to be weighed, sealed and sent in Potaissa.

Is it possible to date these artifacts? For Britain, W. Still observed that the legions garrisoned into the province in the early period of its existence are not attested by sealings. These are legio II Adiutrix, transferred back to the continent from Britain in 87 A.D., legio IX Hispana, which participated to the conquest of Britain in 43 A.D. and probably left the island sometime after 108 A.D., possibly in 121 A.D., and legio XIV Gemina, which left Britain in 67 A.D. At Potaissa, although we do not possess detailed data, it might be possible that the lead sealing discovered in the centuriae from praetentura sinistra indicates, like the vast majority of the artifacts discovered in these barracks, that they were in use mainly in the first half of the third century A.D.

\section{REFERENCES}

BĂRBULESCU 1987

Bărbulescu, M., Din istoria militară a Daciei romane. Legiunea V Macedonica și castrul de la Potaissa (Cluj-Napoca: Dacia).

BĂRBULESCU 1994

Bărbulescu, M., Potaissa. Studiu monografic (Turda: Muzeul de Istorie Turda).

BĂRBULESCU 2004

Bărbulescu, C., Arhitectura militară și tehnica de construcție la romani. Castrul de la Potaissa (Cluj-Napoca: Napoca Star).

BĂRBULESCU 2012

Bărbulescu, M., Inscripțiile din castrul legionar de la Potaissa. The inscription of the legionary fortress at Potaissa (Bucharest: Editura Academiei Române).

BĂRBULESCU 2015

Bărbulescu, M., Arta romană la Potaissa (Cluj-Napoca: Mega).

BĂRBULESCU et alii 2019

Andone Rotaru, M., Bărbulescu, C., Bărbulescu, M., Bărbulescu, T., Cătinaș, A., Fábián, I., Fodorean, F.-G., Huszarik, P., Munteanu, M., Nedelea, L., Nemeti, I., Nemeti, S., Termele din castrul legionar de la Potaissa (Cluj-Napoca: Mega).

DEMBSKI 1975

Dembski, G., Römische Bleisiegel aus Osterreich (Eine Materialvorlage), Römisches Österreich 3, 49-64.

NEMETI et alii 2017

Andone Rotaru, M., Bindea, D., Blaga, D., Fábián, I., Fodorean, F.-G., Munteanu, M., Nedelea, L., Nemeti, I., Nemeti, S., Studii asupra granițelor romane din Dacia. Castrul legionar de la Potaissa. I. Centuriae din praetentura sinistra

\footnotetext{
${ }^{24}$ WILLIAM STILL 1995, I, 104-106.
}

${ }^{25}$ WILLIAM STILL 1995, I, 112.

\author{
(Cluj-Napoca: Mega). \\ PĂSLARU 2009 \\ Pîslaru, M., The Roman Coins from Potaissa. Legionary \\ Fortress and Ancient Town (Cluj-Napoca: Mega). \\ ROSTOVTZEFF/PROU 1900 \\ Rostovtzeff, M., Prou, M., Catalogue des plombs de l'Antiquité, \\ du Moyen Age et des temps modernes conservés au Département \\ des Médailles et Antiques de la Bibliothèque Nationale (Paris: \\ Rollin et Feuardent). \\ TURCAN 1987
}

Turcan, R., Nigra Moneta. Sceaux, felons, tessères, amulettes, plombs monnétaires ou monétiformes, objets divers en plomb ou en etain d'époque romaine conservés an Musée des Beaux-Arts de Lyon (Palais Saint-Pierre) (Lyon).

\section{VONS 1980}

Vons, P., Roman Lead Sealings from Velsen (N.H.), Helinium 20, 44-53.

\section{WILLIAM STILL 1995}

William Still, M. Ch, Roman Lead Sealings, vol. I, vol. II (Ph.D. manuscript), University College London, Institute of Archaeology. Online: http://discovery.ucl.ac.uk/1317870/ 